\title{
PREFERENTIAL UTILIZATION OF CARBOHYDRATE IN DIABETES 1,2
}

\author{
By WALTER R. CAMPBELL AND J. MARKOWITZ \\ (From the Departments of Medicine and Physiology, University of Toronto)
}

(Received for publication October 26, 1926)

\section{INTRODUCTION}

Surveying the history of the treatment of diabetes in man, one finds that persistent attempts have been made from time to time, to feed other carbohydrates than glucose, in the hope that they would be utilized when the power to utilize glucose itself had been seriously interfered with (or in the hope that a greater amount of the substance might be utilized than if glucose were used). So far as we know glucose is the only form in which carbohydrate is ultimately used in the tissues of the normal animal, and if it could be shown that other carbohydrates are better used by the diabetic organism, which we suggest might be called a preferential utilization of the carbohydratea very important principle in the treatment of the diabetic would be established, both from the standpoint of the provision of energy directly through the caloric value of the carbohydrate and because of the additional safeguard which would be provided against ketogenesis, (assuming, of course, that the carbohydrate has antiketogenic properties).

The evidence in favor of preferential utilization of carbohydrate has, at best, been rather meagre and rests principally on clinical observations on diabetes in man. Sometimes the observations have been imperfectly controlled and the results would not today. be admitted in evidence, but even when every precaution has been taken

${ }^{1}$ Read at the 18 th Meeting of the American Society for Clinical Investigation, May 3, 1926. Abstract J. Clin. Invest., 1926, ii, 608.

2 The dihydroxyacetone used in these investigations was purchased by a grant from the John D. Rockefeller, Jr. fund of the Diabetic Clinic, Toronto General Hospital. 
the evidence, interpreted in the light of our present views of diabetes, is not nearly so impressive as it formerly appeared to be. In many cases also the period during which the substance in question was given has not been sufficiently long to allow of any accurate conclusions being drawn, especially because the possibilities of storage of the carbohydrate in the form of glycogen, or blood and tissue sugar, or as fat have been inadequately considered. Less frequently the question of absorption from the gastro-intestinal tract has been a doubtful factor in the interpretation of results. While in the milder cases of diabetes there may have appeared some ground for believing that certain of these substances could be preferentially metabolized it is significant that the earlier conclusions have failed to pass the test of time.

Under certain circumstances it has been shown that more glycogen may be stored, temporarily at least, in the liver of depancreatized animals when carbohydrates other than glucose-levulose for example-are being fed. In all probability a knowledge of this storage has been misleading in the interpretation of the observations in man, for it does not necessarily follow that glycogen storage in the liver bears any relation to the actual burning of carbohydrate in the body (it is without any real significance in the question of preferential utilization of carbohydrate). Ignorance of the production and properties of insulin have also stood in the way of a correct interpretation of the results, especially the facts that the internal secretion of this hormone can be inhibited or stimulated by various means, such as food administration or perhaps exercise, and that it behaves like an enzyme or catalyst in relation to the amount of carbohydrate available in the body for it to act on.

These facts, as well as the uncertainties of the daily production of insulin by the pancreas of diabetic patients, makes it exceedingly difficult to evaluate the results of carbohydrate utilization. We have therefore, attempted in the present investigation to gain more precise knowledge by using depancreatized dogs in which many of these sources of error can be controlled. For those who insist on regarding the diabetes of the depancreatized animal as essentially different from the human disease, the transfer of the problem to the laboratory animal may seem to constitute a fundamental drawback to the applicability 
of the results to man. Since there remains, however, no feature of the human disease which by appropriate treatment cannot be precisely duplicated on the depancreatized animal we do not consider the objection as valid.

\section{EXPERIMENTAL}

Young, adult, female dogs weighing from 7 to $10 \mathrm{kgm}$. were used. The pancreas was entirely removed and the perineum slit under ether anesthesia, after which the animals were placed in metabolism cages and fed twice daily with diet consisting of chopped lean meat (200 grams), raw pancreas (50 grams) and glucose (20 grams). Sufficient insulin was also injected to maintain the animals in nitrogenous equilibrium without, however, entirely suppressing glycosuria. To accomplish this it was found best to inject $10 \mathrm{U}$ insulin into the lumbosacral region daily, at the time of the animals' feeding. They took their food with relish and consumed all of it immediately. By following this routine a known and constant amount of insulin was acting during the period of food absorption, and the animals soon got into excellent bodily condition and recovered and maintained their normal weights. They were kept in this way for some time so that by becoming accustomed to living in the metabolism cage the element of muscular exercise might remain constant. The animals were catheterized and the bladder irrigated at the same hour each morning, just prior to feeding, and the urine thus obtained was added to that passed during the 24 hours, along with the cage washings. Having observed the daily carbohydrate balance on the above diet for some time, an equal weight of levulose, inulin, dihydroxyacetone or glycerol was substituted for the glucose during a four day period, all the other factors remaining the same. This test period was then followed by another control period in which glucose was replaced in the diet of the animal. It may here be stated in parenthesis that we have found that it takes about six hours for complete recovery in the urine of 20 grams of glucose given by mouth, provided water is meanwhile freely allowed the animals.

The urines were analyzed for total sugar by Benedict's copper reduction method, and for fructose, inulin and dihydroxyacetone by polarimetry, fermentation, and by the use of specific tests when necessary. Total nitrogen was determined by the Kjeldahl method. Acetone bodies and inorganic phosphates were determined by Van Slyke's method (1) and by Brigg's method (2) respectively. Since acetone bodies were absent, or at most were present in mere traces, the figures have been omitted from the tables. In the case of inulin the feces were examined for this substance, the periods being marked off by charcoal administration. After the ingestion of dihydroxyacetone or of fructose or inulin the blood was examined for the presence of these substance by the methods which have recently been described by one of us $(3,4)$. The test substances used were high grade products and, if necessary, they were re-purified in the laboratory. The weight of carbohydrate administered was the weight of the anhydrous substance. 


\section{RESULTS}

These are shown in the tables, in which it has been considered unnecessary to include the daily body weights of the animals, since these did vary not for each animal by more than about 120 grams dur-

TABLE 1

Dog F. Levulose

\begin{tabular}{|c|c|c|c|c|}
\hline \multirow{2}{*}{ Date } & \multirow{2}{*}{ Carbohydrate fed } & \multicolumn{2}{|c|}{ Excretion } & \multirow{2}{*}{$\begin{array}{l}\text { Sugar excreted } \\
\text { average }\end{array}$} \\
\hline & & Nitrogen & Sugar & \\
\hline & grams & grams & grams & grams \\
\hline February 4 & Glucose 40 & 14.7 & 23.1 & \\
\hline February 5 & Glucose 40 & 12.5 & 23.9 & \\
\hline February 6 & Glucose 40 & 12.4 & 17.8 & 21.4 \\
\hline February 7 & Glucose 40 & 21.8 & 21.8 & \\
\hline$\cdots \cdots \cdots$ & $\cdots \cdots \cdots \cdots$ & $\cdots \cdots$ & $\cdots \cdots \cdots$ & \\
\hline February 8 & Levulose 40 & 13.6 & 27.7 & \\
\hline February 9 & Levulose 40 & 13.8 & 26.5 & \\
\hline February 10 & Levulose 40 & 13.8 & 25.9 & 25.1 \\
\hline February 11 & Levulose 40 & 14.1 & 22.5 & \\
\hline $\begin{array}{c}\text { February } 12 \\
\end{array}$ & Glucose 40 & $\cdots \ldots$ & 29.0 & \\
\hline February $14^{*}$ & Glucose 40 & 12.9 & 13.2 & 20.8 \\
\hline February 15 & Glucose 40 & 14.0 & 20.2 & \\
\hline February 27 & Glucose 40 & 13.9 & 9.8 & \\
\hline February 28 & Glucose 40 & 14.9 & 18.0 & 200 \\
\hline March 1 & Glucose 40 & 13.3 & 26.8 & 20.9 \\
\hline March 2 & Glucose 40 & 13.1 & 29.2 & \\
\hline$\ldots \ldots \ldots$ & $\ldots \ldots \ldots \ldots$ & & & \\
\hline March 3 & Levulose 40 & 13.0 & 19.6 & \\
\hline March 4 & Levulose 40 & 12.6 & 17.1 & 176 \\
\hline March 5 & Levulose 40 & 12.3 & 13.3 & \\
\hline March 6 & Levulose 40 & 13.4 & 20.4 & \\
\hline $\begin{array}{l}\operatorname{March} 7 \\
\end{array}$ & Glucose 40 & $\begin{array}{l}\ldots \ldots \\
13.1\end{array}$ & 27.7 & \\
\hline March 8 & Glucose 40 & 13.3 & 30.2 & 27.1 \\
\hline March 9 & Glucose 40 & 12.9 & 23.5 & \\
\hline
\end{tabular}

* February 13 , specimen lost.

ing the course of many of the observations. The nitrogen excretion can be seen to have been practically constant from day to day, since it was approximately equal to the nitrogen intake in the food. It 
seems improbable that the animals were either destroying their own tissue protein or were laying on protein or fat in any significant quantity. The daily excretion of carbohydrates was not so constant, but the variability shown is not greater than would be expected in

TABLE 2

Dog III. Levulose

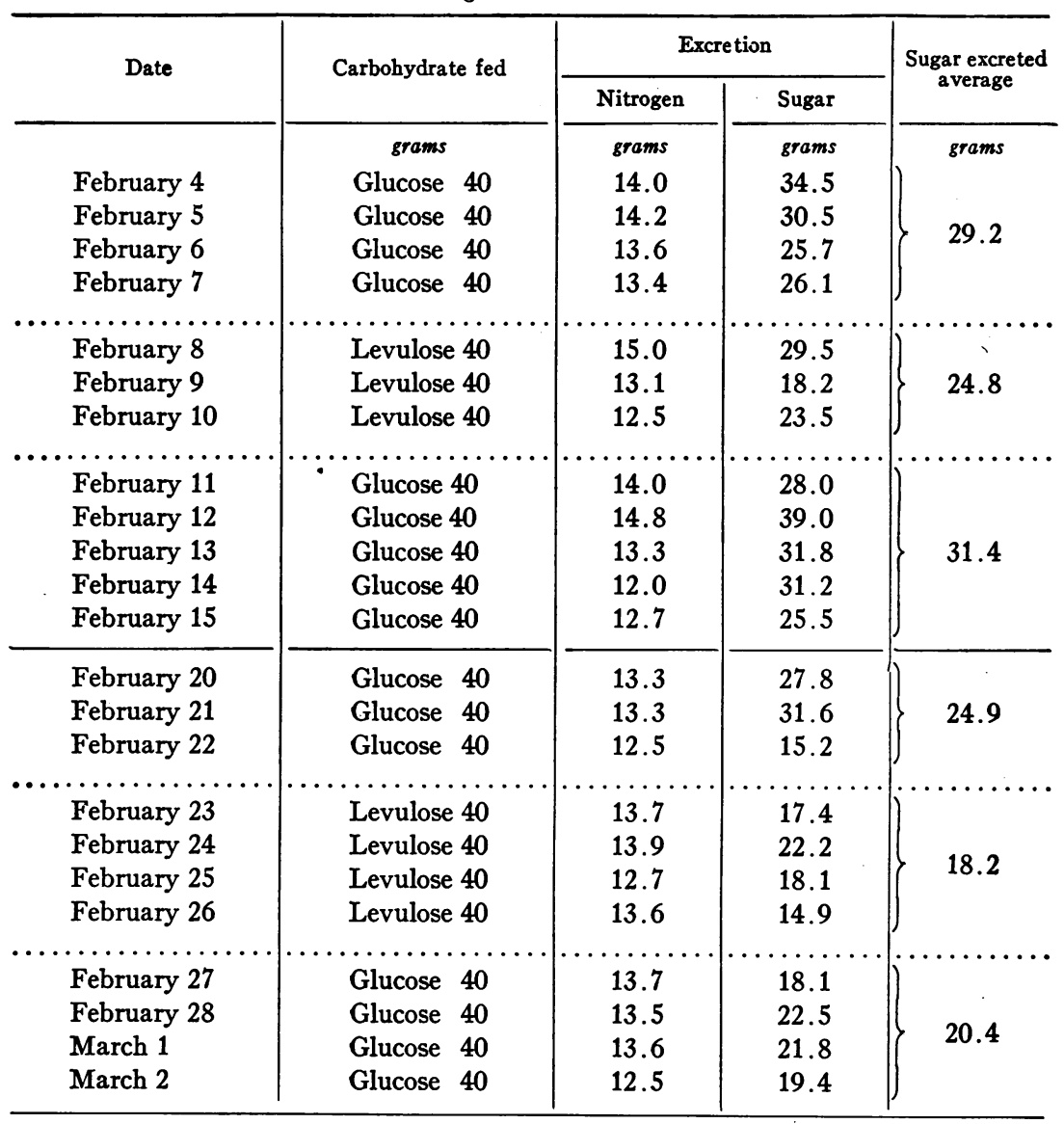

work of this character although it is greater during the test period than during the control periods. It may also be remarked that there was no significant variation in the excretion of inorganic phosphorus, which, however, was relatively high, no doubt because of the larger 
quantities of meat and pancreas contained in the food. It is possible that in view of this high excretion, any changes in relation to carbohydrate metabolism might be masked by the amount of phosphorus being excreted.

Levulose. The observations were made on three dogs, the results on $\operatorname{dog} F$ being shown in table 1 , those on dog 3 in table 2 and those on $\operatorname{dog} 1$ in table 3 . In the interval between the recorded observations the dogs in tables 1 and 2 were kept on the routine diet except that glycerine was substituted for glucose. The results of table 1 show that

TABLE 3

Dog I. Levulose

\begin{tabular}{|c|c|c|c|c|}
\hline \multirow{2}{*}{ Date } & \multirow{2}{*}{ Carbobydrate fed } & \multicolumn{2}{|c|}{ Excretion } & \multirow{2}{*}{$\begin{array}{l}\text { Sugar excreted } \\
\text { average }\end{array}$} \\
\hline & & Nitrogen & Sugar & \\
\hline & grams & grams & grams & grams \\
\hline February 4 & Glucose 40 & 15.1 & 19.8 & \\
\hline February 5 & Glucose 40 & 14.4 & 14.14 & \\
\hline February 6 & Glucose 40 & 14.4 & 16.9 & 10.9 \\
\hline February 7 & Glucose $\mathbf{4 0}$ & 13.7 & 16.7 & \\
\hline February 8 & Levulose $\mathbf{4 0}$ & 13.9 & 14.9 & \\
\hline February 9 & Levulose 40 & 13.9 & 9.1 & \\
\hline February 10 & Levulose 40 & 14.1 & $15: 8$ & 13 \\
\hline February 11 & Levulose $\mathbf{4 0}$ & 13.7 & 12.0 & \\
\hline February 12 & Glucose $\mathbf{4 0}$ & 14.2 & 13.3 & \\
\hline February $14^{*}$ & Glucose 40 & 14.1 & 6.05 & 10.8 \\
\hline February 15 & Glucose 40 & 14.3 & 13.0 & \\
\hline
\end{tabular}

* February 13, specimen lost.

the substitution of levulose for glucose caused an increase in the daily excretion of glucose in the first series of observations, but a decrease of about the same magnitude during the second. The excretion of nitrogen also declined somewhat along with that of glucose in the second period. The grand average for the daily excretion of glucose on all the glucose days of both periods of observation is 22.5 grams as compared with 21.3 for the fructose days. Levulose was detected in small concentration in the urine of these animals qualitatively by Seliwanoff's and Borchardt's reactions but its amount as determined 
by the difference in the copper reduction and polarimetric estimations of sugar was extremely small and would make no significant change in the calculations. Levulose was detected in the blood of the animal

TABLE 4

Dog I. Inulin

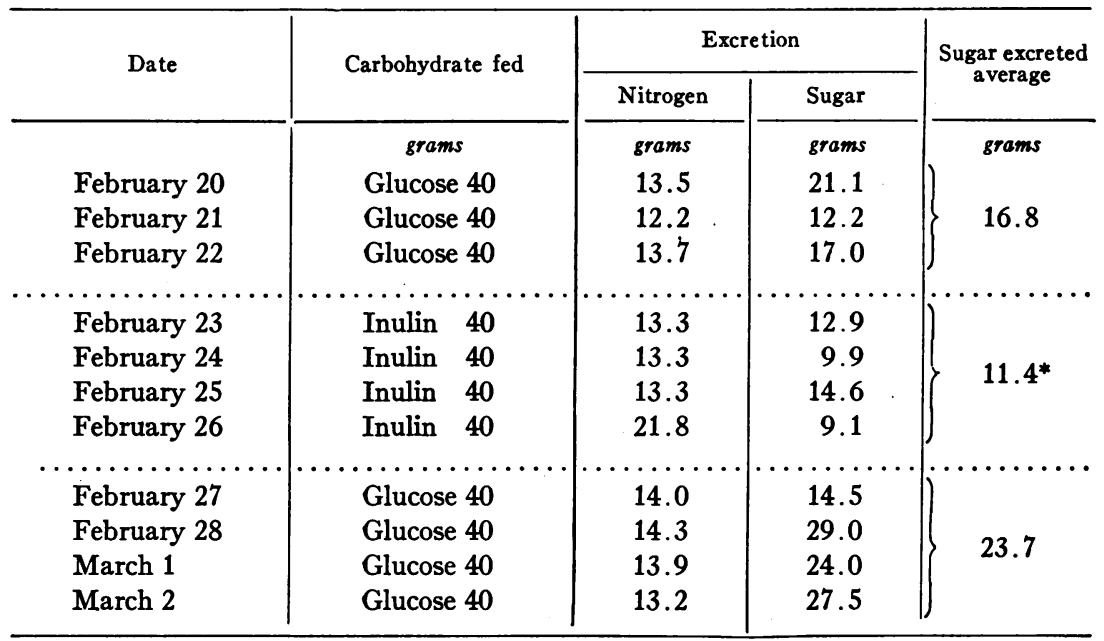

Dog $F . \quad$ Inulin

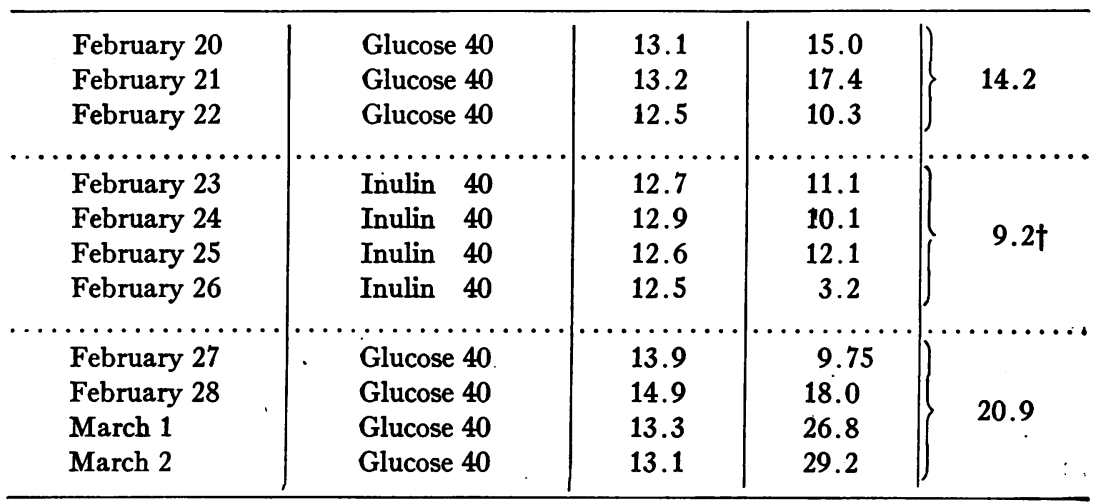

$* 76.3$ grams inulin recovered from feces $=19.1$ grams per day.

† 61 grams inulin recovered from feces $=15.2$ grams per day. Levulose found in blood.

during the period of levulose feeding by the method recently described (4), indicating that the carbohydrate was being absorbed as such and converted to glucose by the organism. 
The results on $\operatorname{dog} 3$ (table 2) show that the carbohydrate excretion was approximately equal or slightly less on the days when levulose was administered than when glucose was given, but the differences are hardly significant. The results on the third dog (table 3) though, unfortunately, incomplete also show slight decreases in both nitrogen and glucose during the levulose periods.

1. Inulin. Table 4 shows the results obtained on two dogs (F and I of tables 1 and 3) when inulin was substituted for glucose in the diet. The inulin used was a high grade commercial product which we

TABLE 5

Dog $F$. Dihydroxyacetone

\begin{tabular}{|c|c|c|c|c|c|}
\hline \multirow{2}{*}{ Date } & \multirow{2}{*}{\multicolumn{2}{|c|}{ Carbohydrate fed }} & \multicolumn{2}{|c|}{ Excretion } & \multirow{2}{*}{$\begin{array}{l}\text { Sugar excreted } \\
\text { average }\end{array}$} \\
\hline & & & Nitrogen & Sugar & \\
\hline & & grams & grams & grams & grams \\
\hline January 28 & Glucose & 40 & 13.4 & 27.8 & \\
\hline January 29 & Glucose & 40 & 13.3 & 19.5 & 18.1 \\
\hline January 30 & Glucose & 40 & 13.9 & 16.7 & \\
\hline January 31 & Dihydro & e 40 & 13.8 & 18.3 & \\
\hline February 1 & Dihydro & e 40 & 13.6 & 22.7 & 106 \\
\hline February 2 & Dihydro & e 40 & 13.6 & 19.3 & 19.0 \\
\hline February 3 & Dihydro & e 40 & 13.4 & 18.2 & \\
\hline February 4 & Glucose & 40 & 14.7 & 23.1 & \\
\hline February 5 & Glucose & 40 & 12.5 & 23.9 & 214 \\
\hline February 6 & Glucose & 40 & 12.4 & 17.8 & 21.4 \\
\hline February 7 & & & 14.4 & 21.8 & ) \\
\hline
\end{tabular}

reprecipitated by alcohol. It contained no glucose or sucrose and little, if any, levulose. After drying at $110^{\circ} \mathrm{C}$. it analyzed over 99.5 per cent inulin. It can be seen that decidedly less glucose was excreted on the days during which this polysaccharide was substituted for glucose. This is adequately accounted for by an imperfect absorption, for the decreased excretion coincides with a failure to absorb an average of 15 to 20 grams of inulin per day, which was recovered from the feces of the animal. The fact that levulose was detected in the blood is evidence that the unrecovered inulin was not wholly destroyed by bacterial enzymes and that part of the inulin was 
absorbed. This no doubt furnished the source for the urinary glucose since the unchanged or even slightly decreased nitrogen output, as compared with the control days, is evidence against increased protein

TABLE 6

Dog I. Dihydroxyacetone

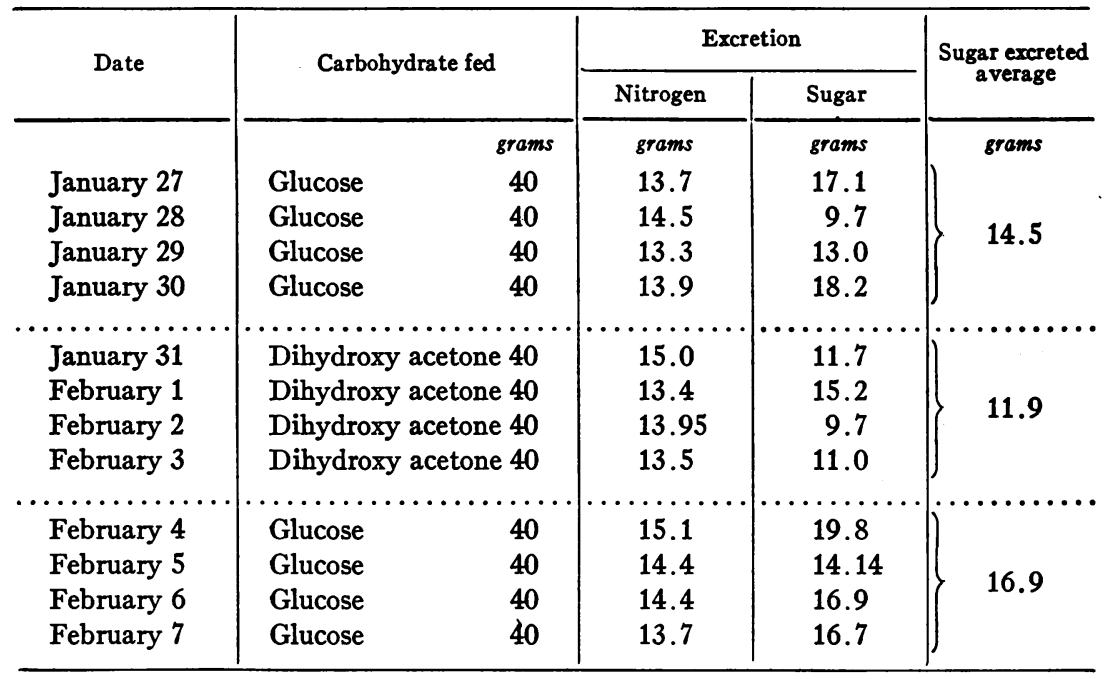

Same dog. Same routine except 20 grams carbohydrate and 6 units insulin

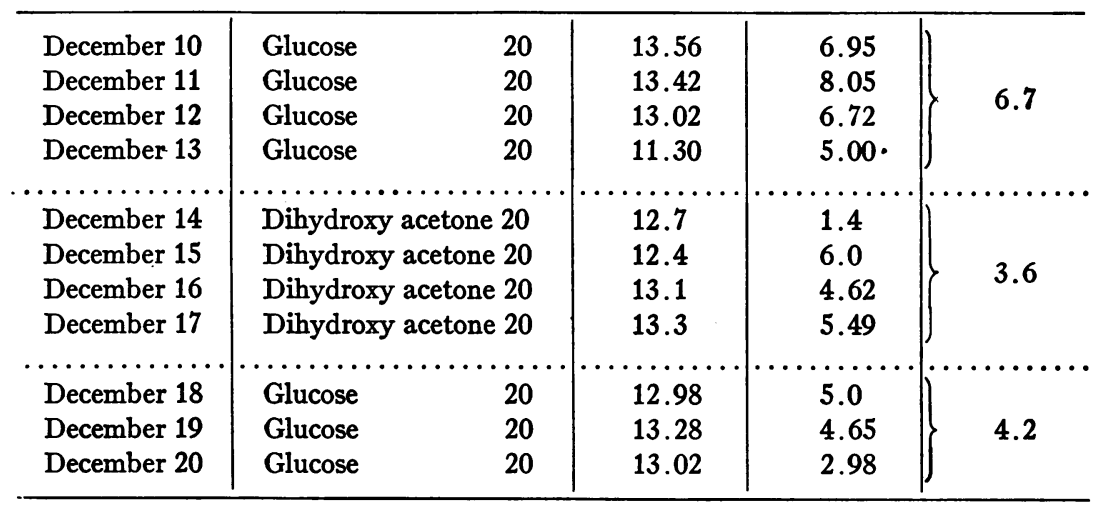

destruction being responsible for the sugar. It is worthy of note that the excretion of sugar in the control period following the administration of inulin is in each case greater than in the preliminary control 
period but the explanation for this occurrence is not apparent. It is not accompanied by any significant change in nitrogen excretion. Allowing for the fact that forty grams of inulin is equivalent to 44

TABLE 7

Dog III. Dihydroxyacetone

\begin{tabular}{|c|c|c|c|c|c|}
\hline \multirow{2}{*}{ Date } & \multirow{2}{*}{\multicolumn{2}{|c|}{ Carbohydrate fed }} & \multicolumn{2}{|c|}{ Excretion } & \multirow{2}{*}{$\begin{array}{l}\text { Sugar excreted } \\
\text { a verage }\end{array}$} \\
\hline & & & Nitrogen & Sugar & \\
\hline & & grams & grams & grams & grams \\
\hline January 27 & Glucose & 40 & 13.9 & 26.25 & \\
\hline January 28 & Glucose & 40 & 14.1 & 25.00 & 258 \\
\hline January 29 & Glucose & 40 & 12.4 & 18.10 & 20.0 \\
\hline January 30 & Glucose & 40 & 14.1 & 34.00 & \\
\hline n.......... & $\cdots \cdots$ & $\cdots \cdot$ & $\cdots \cdots$ & & \\
\hline January 31 & Dihydro & e 40 & 14.0 & 17.8 & \\
\hline February 1 & Dihydro & e 40 & 12.2 & 13.3 & 202 \\
\hline February 2 & & ple los & & & 20.2 \\
\hline February 3 & Dihydros & e 40 & 13.5 & 29.5 & \\
\hline n......... & . & & ........ & & \\
\hline February 4 & Glucose & 40 & 14.0 & 34.5 & \\
\hline February 5 & Glucose & 40 & 14.2 & 30.5 & 292 \\
\hline February 6 & Glucose & 40 & 13.6 & 25.7 & 27.2 \\
\hline February 7 & Glucose & 40 & 13.4 & 26.1 & 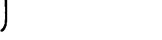 \\
\hline
\end{tabular}

Dog III. Known diet 2 days

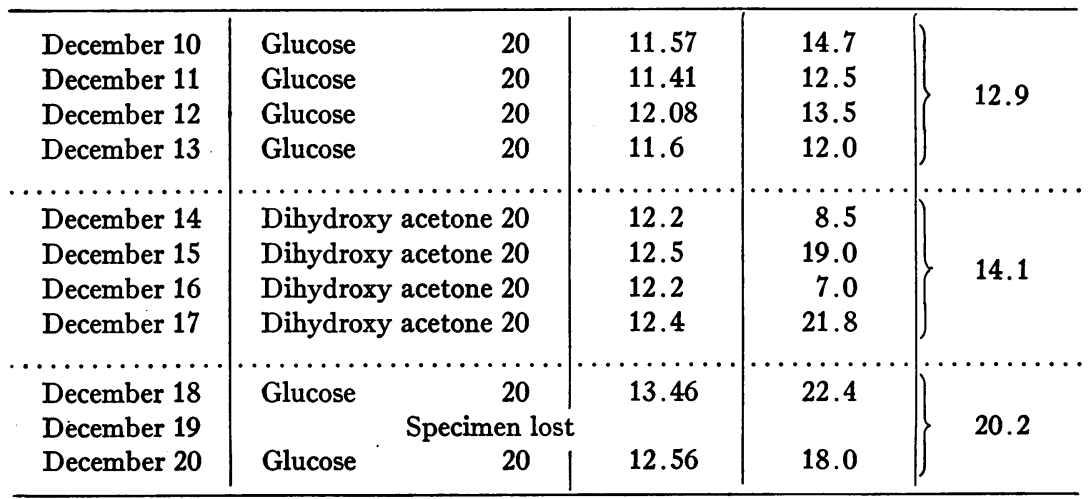

grams of levulose, the sum of the glucose excreted in the urine plus the inulin recovered from the feces is practically the same as the glucose excretion on the control days, so that the results are interpreted as 
showing that inulin is metabolized by the partially diabetic organism to the same extent as glucose. (From this evidence as well as from the known chemical instability of inulin it would seem inadvisable to regard it as an indifferent substance wholly unmetabolized by the diabetic. On the other hand there is no evidence that it is metabolized by the diabetic organism with any greater facility than is glucose.)

Dihydroxyacetone. The results of the experiments when dihydroxyacetone was used as the test substance are shown in tables 5 to 7 the same animals being used as in tables 1-3. The results in table 5 show no change in the glucose excretion during the period in which dihydroxyacetone was substituted for glucose. In arriving at this conclusion we have omitted from the averages of the preliminary control period the excessive glucose excretion of the first day, which no doubt was due to the fact that the animal had only been placed on the weighed diet on the previous day.

In tables 6 and 7 the results sometimes show a slight decrease in glucose excretion in the periods during which dihydroxyacetone was substituted, but this cannot be taken as evidence of a preferential utilization of this substance over glucose. It is probably to be accounted for by some of the dihydroxyacetone which escapes conversion into glucose during its passage through the liver being absorbed and stored in the tissues in which normally none of this substance is present. As the tissues become thus loaded with unconverted dihydroxyacetone a part will no doubt gradually return to the blood and increase the glucose production, and it may be on account of this that a tendency can be seen in certain of the observation for the glycosuria to become greater on the last day or so of dihydroxyacetone administration, as well as during the first few days of the subsequent glucose control period.

A somewhat different type of experiment is recorded in table 8. A dog, recently depancreatized and thereafter on a variable diet containing meat, raw pancreas and sugar with insulin, was given 200 grams meat, 50 grams pancreas and 40 grams sucrose with 10 units of insulin twice daily. As the glucose excretion kept falling in all probability our three preliminary control days do not represent an equilibrium between utilization and excretion of carbohydrate. For four days the animal was then given 20 grams dihydroxyacetone in addition to the sucrose 
in the diet, in two partions of 10 grams each per day. This period is followed by a second control period of four days. The average of the seven control days' excretion of carbohydrate is 13.2 grams. Averaging the four days after control periods gives 10.4 grams of glucose. The average glucose excretion in the test period is 27.4 grams. The excess excretion of sugar during this period is 14.2 to 17 grams. The difference between the amount of extra carbohydrate fed and the

TABLE 8

Dog I. Dihydroxyacetone

\begin{tabular}{|c|c|c|c|c|c|}
\hline \multirow{2}{*}{ Date } & \multirow{2}{*}{\multicolumn{2}{|c|}{ Carbohydrate fed }} & \multicolumn{2}{|c|}{ Excretion } & \multirow{2}{*}{$\begin{array}{l}\text { Sugar excreted } \\
\text { average }\end{array}$} \\
\hline & & & Nitrogen & Sugar & \\
\hline & & grams & grams & grams & grams \\
\hline November 20 & Sucrose & 40 & 13.6 & 21.7 & \\
\hline November 21 & Sucrose & 40 & 13.1 & 16.2 & 13.2 \\
\hline November 22 & Sucrose & 40 & 12.7 & 12.6 & \\
\hline \multirow{2}{*}{ November 23} & an. & & & & \multirow{8}{*}{$\begin{array}{r}\cdots \cdots \cdots \\
27.4\end{array}$} \\
\hline & $\begin{array}{l}\text { Sucrose } \\
\text { + Dioxy }\end{array}$ & $\begin{array}{l}40 \\
20\end{array}$ & 13.0 & 27.5 & \\
\hline \multirow[t]{2}{*}{ November 24} & Sucrose & 40 & \multirow{2}{*}{13.5} & \multirow{2}{*}{30.4} & \\
\hline & + Dioxy & 20 & & & \\
\hline \multirow[t]{2}{*}{ November 25} & Sucrose & 40 & \multirow{2}{*}{13.6} & \multirow{2}{*}{25.6} & \\
\hline & + Dioxy & 20 & & & \\
\hline \multirow{2}{*}{ November 26} & Sucrose & 40 & \multirow{2}{*}{13.5} & \multirow{2}{*}{26.1} & \\
\hline & + Dioxy & 20 & & & \\
\hline & $\cdots \cdots \cdots$ & (P) & & & \\
\hline November 27 & Sucrose & 40 & 13.3 & 7.60 & \\
\hline November 28 & Sucrose & 40 & 13.4 & 7.05 & \\
\hline November 29 & Sucrose & 40 & 14.6 & 13.40 & 10.4 \\
\hline November 30 & Sucrose & 40 & 12.2 & 13.70 & \\
\hline
\end{tabular}

increased excretion is not, however, evidence of preferential utilization of the dihydroxyacetone. Should dihydroxyacetone be the intermediate stage between glucose and $\mathrm{CO}_{2}$ and the water, as has been thought, it should have been wholly metabolized without insulin. As has been shown elsewhere (5) when insulin is absent no dihydroxyacetone is burned by the depancreatized animal. The small discrepancy between recovered extra glucose and dihydroxyacetone 
TABLE 9

Dog $F$. Glycerine

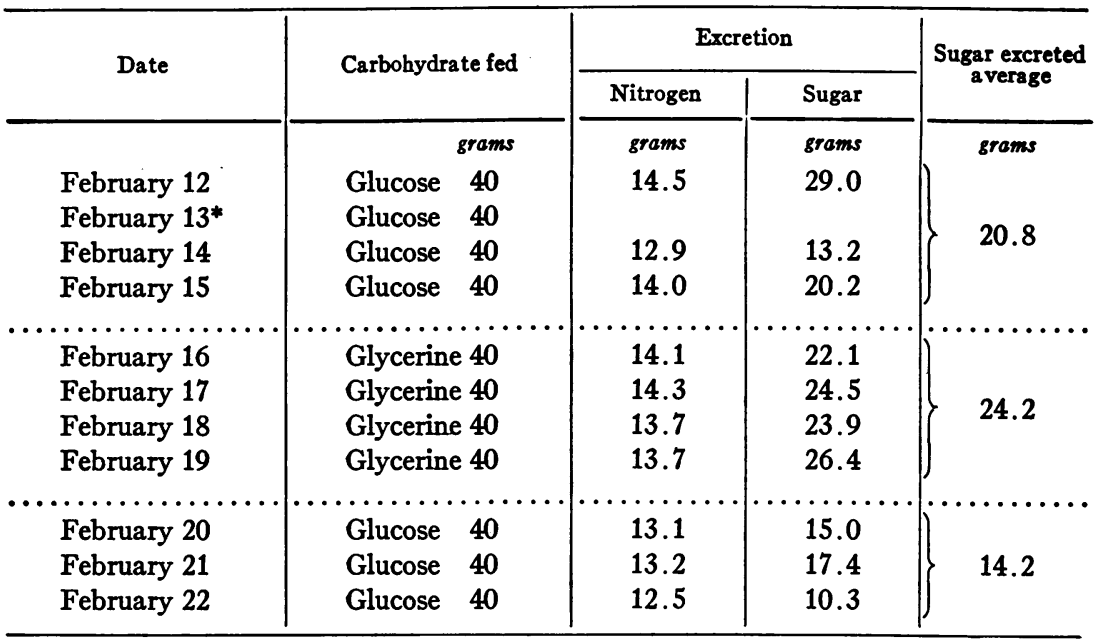

Dog I. Glycerine

\begin{tabular}{|c|c|c|c|c|}
\hline $\begin{array}{l}\text { February } 12 \\
\text { February } 14 \\
\text { February } 15\end{array}$ & $\begin{array}{ll}\text { Glucose } & 40 \\
\text { Glucose } & 40 \\
\text { Glucose } & 40\end{array}$ & $\begin{array}{l}14.2 \\
14.1 \\
14.3\end{array}$ & $\begin{array}{r}13.3 \\
6.1 \\
13.0\end{array}$ & 10.8 \\
\hline $\begin{array}{l}\text { February } 16 \\
\text { February } 17 \\
\text { February } 18 \\
\text { February } 19\end{array}$ & $\begin{array}{l}\text { Glycerine } 40 \\
\text { Glycerine } 40 \\
\text { Glycerine } 40 \\
\text { Glycerine } 40\end{array}$ & $\begin{array}{l}14.3 \\
14.4 \\
15.2 \\
13.5\end{array}$ & $\begin{array}{r}13.6 \\
9.7 \\
12.2 \\
13.6\end{array}$ & 12.4 \\
\hline $\begin{array}{l}\text { February } 20 \\
\text { February } 21 \\
\text { February } 22\end{array}$ & $\begin{array}{ll}\text { Glucose } & 40 \\
\text { Glucose } & 40 \\
\text { Glucose } & 40\end{array}$ & $\begin{array}{l}13.5 \\
12.2 \\
13.7\end{array}$ & $\begin{array}{l}21.1 \\
12.2 \\
17.0\end{array}$ & 16.4 \\
\hline \multicolumn{5}{|c|}{ Dog III. Glycerine } \\
\hline $\begin{array}{l}\text { February } 11 \\
\text { February } 12 \\
\text { February } 13 \\
\text { February } 14 \\
\text { February } 15\end{array}$ & $\begin{array}{ll}\text { Glucose } & 40 \\
\text { Glucose } & 40 \\
\text { Glucose } & 40 \\
\text { Glucose } & 40 \\
\text { Glucose } & 40\end{array}$ & $\begin{array}{l}14.0 \\
14.8 \\
13.3 \\
12.0 \\
12.7\end{array}$ & $\begin{array}{l}28.0 \\
39.0 \\
31.8 \\
31.2 \\
25.5\end{array}$ & 31.4 \\
\hline $\begin{array}{l}\text { February } 16 \\
\text { February } 17 \\
\text { February } 18 \\
\text { February } 19\end{array}$ & $\begin{array}{l}\text { Glycerine } 40 \\
\text { Glycerine } 40 \\
\text { Glycerine } 40 \\
\text { Glycerine } 40\end{array}$ & $\begin{array}{l}1 \ldots . . \\
14.2 \\
14.3 \\
13.9 \\
13.2\end{array}$ & $\begin{array}{l}\cdots \\
17.8 \\
28.0 \\
30.8 \\
30.1\end{array}$ & 25.7 \\
\hline $\begin{array}{l}\text { February } 20 \\
\text { February } 21 \\
\text { February } 22\end{array}$ & $\begin{array}{ll}\text { Glucose } & 40 \\
\text { Glucose } & 40 \\
\text { Glucose } & 40\end{array}$ & $\begin{array}{l}13.3 \\
13.3 \\
12.5\end{array}$ & $\begin{array}{l}27.8 \\
31.6 \\
15.2\end{array}$ & 24.8 \\
\hline
\end{tabular}

* Specimen lost. 
administered is due to the logarithmic or enzymic action of insulin so clearly shown by Frank Allan (6) and the discrepaney occurs also with added glucose as the substrate. It does not, in our opinion, justify the prescription of additional carbohydrate in the form of dihydroxyacetone for the diabetic patient whose pancreas is already working near the limit of its tolerance, to any greater degree than it justifies the prescription of additional glucose.

Glycerine. Glycerine is an alcohol and not a carbohydrate in the strict sense. On account of its palatability and its food value it has been recommended for the treatment of diabetic patients. Table 9 shows the results obtained on three of the dogs used in the preceding observations when this substance is substituted for glucose in the diet of depancreatized animals receiving constant doses of insulin. In the observation on $\operatorname{dog} \mathrm{F}$ there is apparently a greater excretion of sugar after the administration of glycerine than when glucose itself is given, but in those on the other two dogs the glucose excretion is approximately equal in the control periods and test periods. There is a possibility that these differences are related to the nutritional condition of the animal in some way, the first dog $(F)$ having a large amount of subcutaneous body fat while the other two dogs were merely well nourished animals. There is no evidence, however, that in any of these animals, glycerine is preferentially metabolized as compared with glucose.

\section{DISCUSSION}

Reviewing the foregoing results as a whole it can be concluded with confidence that there is no essential difference between the utilization of glucose and that of levulose, inulin, dihydroxyacetone or glycerine in depancreatized animals that are kept in a constant state of partial diabetes by the frequent injection of moderate doses of insulin. The results are obviously more conclusive that those which it is possible to obtain with diabetic patients. Even in the most extreme instances of this disease it is improbable that all of the insular tissue of the pancreas has become so destroyed that it can secrete no insulin, and in the vast majority of cases a considerable internal secretion of this hormone must still be possible. And herein, in our judgment, lies 
one important source of inaccuracy in the clinical observations which have hitherto been made concerning the preferential utilization of carbohydrate and related substances, for it is evident if any internal secretion of insulin occurs that it will vary from time to time, subject not only to dietetic and metabolic conditions, but also to nervous control. When for any reason more insulin comes to be secreted there will result immediately, a better utilization of carbohydrate, and subsequently, when the secretion falls off again, an excess of glucose will appear in the organism because of the breakdown of the enhanced glycogen stores. If these changes coincide with alterations in diet they may appear to be related to them.

It is almost certain also that serious errors have been incurred in the interpretation of the clinical results on account of no allowance having been made for the fact, clearly demonstrated in this laboratory by Allan, that increase in the ingestion of carbohydrate in depancreatized animals receiving a constant amount of glucose, is not followed by a proportionate increase in the glycosuria. As the amount of available glucose in the body increases in relation to insulin the glucose equivalent of each unit becomes greater and greater. In the dihydroxyacetone experiments as already remarked, it is almost certain that a part of the absorbed substance is not immediately converted into glucose but is absorbed and retained for some time by the tissues so that a decrease in glucose excretion is to be expected.

If, as we believe, these results are directly transferable to the patient the inference is that the attempt to use larger quantities of these substances than glucose itself, or other glucose precursors, will result in a strain on the patient's pancreas which will eventually succeed in decreasing his tolerance for carbohydrate. 'Eventually' is used advisedly in this connection since it is well known that temporary excesses in carbohydrate are apparently well borne for a time. Two mechanisms may be called upon to accomplish this. Increasing the amount of carbohydrate (the substrate) may increase the amount of enzyme action of the available insulin as shown by Allan (6), or stimulation of the damaged pancreas may temporarily produce more insulin. Probably both mechanisms occur, but in either case it is a sound principle not to require of a damaged organ its maximal activity. 


\section{SUMMARY}

A new method of studying the question of preferential metabolism of certain carbohydrates or related substances is presented. This consists in feeding to depancreatized animals receiving insulin known quantities of the test substance in substitution for equal amounts of glucose. The results obtained by this method on levulose, inulin, dihydroxyacetone and glycerine afford no evidence that greater quantities can be utilized by the diabetic organism than of glucose itself. This suggests that these substances must pass through a glucose phase in their metabolism, and, therefore, do not undergo any preferential utilization as compared with other carbohydrates. The application of these results to the treatment of human diabetes mellitus is indicated.

In conclusion, the writers wish to express their thanks to Professor Macleod for his kindness in providing facilities for this investigation.

\section{BIBLIOGRAPHY}

1. Van Slyke, D. D., Jour. Biol. Chem., 1917, xxxii, 455. Studies of Acidosis. VII. The Determination of $\beta$-Hydroxybutyric Acid, Acetoacetic Acid and Acetone in Urine.

2. Briggs, A. P., Jour. Biol. Chem., 1922, liii, 13. A Modification of the BellDoisy Phosphate Method.

3. Campbell, W. R., Jour. Biol. Chem., 1926, lxvii, 59. The Quantitative Determination of Dihydroxyacetone.

4. Campbell, W. R., and Hanna, M. I., Jour. Biol. Chem., 1926, lxix, 703. The Estimation of Fructose, Sucrose and Inulin.

5. Campbell, W. R., and Markowitz, J., Am. Jour. Physiol., (in press).

6. Allan, F. N., Am. Jour. Physiol., 1924, lxvii, 275. The Glucose Equivalent of Insulin in Depancreated Dogs. 